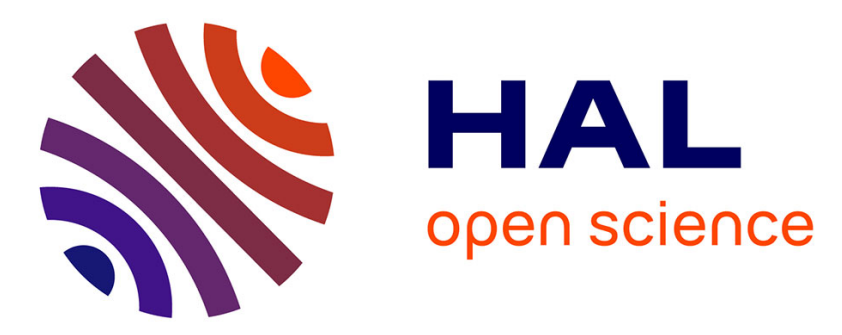

\title{
Application of laser scanning image cytometry for human chromosome microdissection and DNA analysis
}

P. Métézeau, G. Tachdjian, H. Kiefer, L. Druart, V. Cacheux, C. Nessmann, G. Lizard

\section{- To cite this version:}

P. Métézeau, G. Tachdjian, H. Kiefer, L. Druart, V. Cacheux, et al.. Application of laser scanning image cytometry for human chromosome microdissection and DNA analysis. Journal de Physique IV Proceedings, 1994, 04 (C4), pp.C4-265-C4-268. 10.1051/jp4:1994461 . jpa-00252724

HAL Id: jpa-00252724

https://hal.science/jpa-00252724

Submitted on 1 Jan 1994

HAL is a multi-disciplinary open access archive for the deposit and dissemination of scientific research documents, whether they are published or not. The documents may come from teaching and research institutions in France or abroad, or from public or private research centers.
L'archive ouverte pluridisciplinaire HAL, est destinée au dépôt et à la diffusion de documents scientifiques de niveau recherche, publiés ou non, émanant des établissements d'enseignement et de recherche français ou étrangers, des laboratoires publics ou privés. 


\section{Application of laser scanning image cytometry for human chromosome microdissection and DNA analysis}

P. MÉTÉZEAU, G. TACHDJIAN* ${ }^{*}$ H. KIEFER, L. DRUART*, V. CACHEUX* , C. NESSMANN* and G. LIZARD**

Biochimie Cellulaire et Cytométrie Analytique et Préparative, SC 9 INSERM-Pasteur, 28 rue du Dr Roux, 75724 Paris cedex 15, France

* Unité de Cytogénétique, Service de Biologie du Développement et de la Reproduction, Hôpital Robert Debré, 48 Boulevard Sérurier, 75019 Paris, France

${ }^{* *}$ Centre Commun Cytométrie en Flux, Hôpital E. Herriot, Place d'Arsonval, 69437 Lyon cedex 03, France

\section{INTRODUCTION}

Recent progress in molecular biology have increased the use of chromosomal microdissection in human genetics (Kao and Yu, 1991; Seki et al., 1993). Indeed, generation of DNA probes from genome is of great interest in Genetics. This objective can be obtained by using microdissection and amplification of a desired chromosomal region (Ludecke et al., 1989; Meltzer et al., 1992). We describe here application of laser scanning image cytometry for human chromosome microdissection and DNA analysis.

\section{MATERIALS AND METHODS}

\section{Chromosome preparation}

Phytohemagglutinin-stimulated human lymphocyte cultures were established from healthy donors. Metaphase spreads were prepared according to our standard protocoles.

\section{Laser microdissection}

The laser microdissection of the chromosomes was performed on chromosomes stained with Giemsa $0.5 \%$. Conditions adopted for current microdissection were obtained with 
an argon ion laser (Coherent $92-5$, Palo Alto, $\mathrm{Ca}$, USA) emitted beam at $488 \mathrm{~nm}$, with a $50 \mathrm{~mW}$ power reduced to $12.5 \mathrm{~mW}$ by an acousto optic modulator. A $100 \mathrm{X}$ immersion oil objective lens allowed to obtain a laser spot diameter of $0.2 \mu \mathrm{m}$. The effective power at the plane of focus was determined using a power meter field Master with a detector head LM-2 (Coherent). For manual burning, the deplacement of laser beam was controlled with a mouse by a computer and directly monitored by a TV display. All these experimental conditions were realised by using the image cytometer ACAS 570 (Meridian, Okemos, Mi, USA).

\section{RESULTS}

Laser microdissection was performed on non stained and stained chromosomes with Giemsa $0.5 \%$ and on GTG banded chromosomes. On non stained chromosomes, aspect of the chromosomes was not modified, whatever the laser power used. The concentration and staining time of Giemsa were important parameters to visualize the effects of the laser beam on the chromosomes. Burning of chromosomes with intense staining led to a blackening of the chromosomes, and with weak staining to a whitening of the chromosomes. All the chromosomes of one metaphase except one precise chromosomal region have been burnt in a few minutes.

\section{DISCUSSION}

The method described allows a precise and rapid microdissection of any chromosomal region from a metaphase. A laser scanning image cytometer have been used to microdissect chromosome. Laser is based on the fact that at high photon densities light can liquefy, evaporate or break down optically biological material (Letokhov, 1985). To obtain an optimal laser power stability in these weak values and to attenuate laser beam irradiations, we used an acoustico optic modulator. The effects of these different laser beam powers were analysed by the alterations of the stained chromosome. A weak Giemsa staining was necessary to visualize the action of the laser beam on the chromosomes. With no stained chromosomes, we did not observe aiterations of DNA. However, the effects of the laser beam were not similar using different Giemsa 
concentrations. With a low concentration of Giemsa, staining disappeared, and the destruction of the chromosomes was easily visualised. In opposition, a high concentration of Giemsa led to a blackening of the chromosomes and did not allow the visual differenciation between the burnt and non burnt chromosomes. When the light power used was high, the whitening of burnt chromosomes was not similar to that observed in our finally adopted experimental conditions. Laser power under $5 \mathrm{~mW}$ was not sufficient to destroy the chromosome. Destruction of all the metaphase excepted one chromosomal fragment was extremely rapid and required about 2 min. To destroy chromosomes, the laser burning intensity was lower than the usually generally used 100$300 \mathrm{~mW}$ laser power, corresponding probably to a lower power in the plane of sample to kill whole cells by the same system (Schindler et al., 1985). Size of the laser beam depended with the objective utilized. With a X100 immersion oil objective, it was of $0.2 \mu \mathrm{m}$. This value corresponds approximatively to 30 megabases in metaphase (Monajembashi et al., 1986). The experiments presented in this work demonstrate the feasibility and simplicity of laser microdissection of the chromosomes.

\section{REFERENCES}

Kao FT, Yu JW: Chromosome microdissection and cloning in human genome and genetic disease analysis. Proc Natl Acad Sci USA88:1844-1848, 1991.

Letokhov VS. Laser biology and medicine. Nature 316:325-330, 1985.

Ludecke HJ, Senger G, Claussen U, Horsthemke B: Cloning defined regions of the human genome by microdissection of banded chromosomes and enzymatic amplification. Nature 338:348-350, 1989.

Meltzer PS, Guan XY, Burgess A, Trent J: Rapid generation of region specific probes by chromosome microdissection and their application. Nature Genet 1:24-28, 1992. 
Monajembashi S, Cremer C, Cremer T, Wolfrum J, Greulich KO: Microdissection of human chromosomes by a laser microbeam. ExpCell Res 167:262-265, 1986.

Schindler M, Allen ML, Ollingen MR, Holland JF: Automated analysis and survival selection of anchorage-dependent cells under normal growth conditions. Cytometry 6 : $368-374,1985$.

Seki N, Yamauchi M, Saito Y, Katakura R, Ohta T, Yoshiura KI, Jinno Y, Niikawa N, Hori TA: Microdissection and microcloning of genomic DNA markers from human chromosomal region 11q23. Genomics16:169-172, 1993.

\section{AKNOWLEDGEMENTS}

We are grateful to Pr M.E. Goldberg and B. Baron for fruitful discussion. We thank Cytolab and Coherent for technical assistance. This work was partly supported by the "Association Génétique et Développement Foetal" (AGDF). 